\title{
Macroeconomic Drivers of Stock Market Development: Evidence From Jordan
}

\author{
Alaaeddin Al-Tarawneh ${ }^{1} \&$ Ghazi Al-Assaf ${ }^{1}$ \\ ${ }^{1}$ Business Economics Department, School of Business, University of Jordan, Amman, Jordan \\ Correspondence: Alaaeddin Al-Tarawneh, Business Economics Department, School of Business, University of \\ Jordan, Amman, Jordan.
}

Received: June 29, 2018

Accepted: July 23, 2018

Online Published: July 29, 2018

doi:10.5430/ijfr.v9n3p117

URL: https://doi.org/10.5430/ijfr.v9n3p117

\begin{abstract}
This paper investigates the macroeconomic drivers of the stock market development in Jordan during the period 1978-2016. The macroeconomic variables are represented by remittance inflows, investment, banking sector development, and level of income. The paper employs the ARDL bounds testing procedure to estimate the potential short run and long run relationships between the stock market development indicator and macroeconomic variables. The empirical results show that the macroeconomic variables positively and significantly affect the development of stock market in Jordan, except remittances which has a negative effect on the stock market development indicator. All signs and magnitudes are consistent with the literature.
\end{abstract}

Keywords: macroeconomics determinants, stock market development, ARDL, Jordan

JEL: E22, G14, C52, C53

\section{Introduction}

An increased interest in the relationship between macroeconomic variables and the development of stock markets were discussed by respective number of studies for many countries. As macroeconomic variables found to affect significantly the performance of the stock market, many studies linked the economic activities with the stock market development. The main role of the financial system is to facilitate saving borrowing transactions, also it helps to improve funds allocation. It is approved, by many studies, that there is a significant relationship between stock markets and the economic growth.

Although substantial attention given to study the relationship between stock markets and economic growth, there is a small number of empirical work studied the determinants of stock market development, especially in the developing economies such as Jordan. Therefore, this paper contributes to the literature by conducting an empirical analysis using ARDL model to examine both short run and long run relationships between the stock market development in Jordan and its main determinants, by employing recent time series and providing evidence whether macroeconomic variables lead to the stock market development.

The rest of this paper is organized as follow. Section 2 reviews the literature on the relationship between macroeconomic variables and stock market development. Section 3 represents the data used in the empirical estimation and the model specification. The next section reports the results of the tests and empirical estimation. The last section concludes.

\section{Literature Review}

In general, the interactions between macroeconomic variables and financial development have been a controversial topic among researchers and policy makers. However, this relationship has been frequently investigated in the empirical literature, where the developmental impact of macroeconomic variables in developing countries has been a growing area of interest for many researchers and policymakers. This area of interest acquires significance through the fact that financial sector performs a number of key economic functions and its development will lead to foster economic growth and increase level of income.

In addition, there is no doubt that channelling remittance transfers through the banking system and directing them to stock markets will help to multiply the development impact of workers' remittances in recipient countries. Billmeier 
and Massa (2009) analyse the macroeconomic determinants of stock market development using remittances as a key factor that affect market capitalisation behaviour of the stock market. A panel analysis of 17 emerging economies in the Middle East and Central Asia region, over the period 1995-2005, is employed in order to investigate the macroeconomic determinants of stock market development in oil versus non-oil economies. The study uses a fixed-effect panel, where market capitalisation as a share of GDP is the measure used to represent the degree of stock market development, including remittances, investment, domestic credit, and stock traded (normalised by GDP) as the main explanatory variables in the model.

Raza et al. (2015) investigate the impact of foreign capital inflows and remittances and economic growth on stock market capitalization for the case of Pakistan. Using the ARDL techniques, the empirical results indicate that foreign direct investment, workers' remittances and economic growth have significant positive relationship with the stock market capitalization in long run as well as in short run.

Most of the previous literature on the impact of remittances on financial development has focused on the banking sector side ignoring the stock market side. The empirical results of Aggarwal \& Peria (2006) reveal that remittances affect financial development positively through increasing the aggregate level of total deposits held by commercial banks and the credit intermediated by these banks. The results show that the effects of remittances on total bank deposits are almost twice as large as the effects on banks credit facilities. However, research has also shown that workers' remittances can help to foster the economic growth through improving financial development. Giuliano and Arranz (2005), Mundaca (2005), and Prakash (2009) examine the linkage between remittances and economic growth, based on the level of financial development in a country.

Although examining the linkage between financial development and macroeconomic variables usually requires evaluation, an evaluation of stock market development, since the stock market development is an integral part of financial development. Economists have recently turned their attention to study the determinants of the stock market development. Garcia\& Liu (1999) first investigates the macroeconomic determinants of the development of stock market in number of developed and developing countries, using pooled data over the period 1980-1995. The results show that the important macroeconomic determinants of stock market capitalization including; real income, saving rate, financial intermediary development, and stock market liquidity. A number of recent papers (Kemboi \& Tarus (2013); Sukruoglu \& Nalin (2014); Ho (2017); Matadeen (2017)) studied the macroeconomic drivers of stock market development. These studies agreed that the income, investment, banking sector development, and stock market liquidity are the main determinants of the stock market development.

A comprehensive review of the literature on the stock market development was provided by Ho \& Njindan (2017). Another paper for Ho \& Odhiambo (2018) studied the impact of number of variables on the development of the stock market in Philippine, using quarterly data covering the period 2001-2016. The study uses the ARDL bounds testing procedure, and finds that trade openness has long-run negative impact, where both banking sector development and the exchange rate have short-run positive impact on the stock market development. On the other hand, Kumar and Batra (2017) also examine the potential inter linkages between stock market index and macroeconomic variables for India covering the period 1991-2016. They clearly found a long run positive relation between stock market index and macroeconomic variables particularly exchange rate, interest rate, foreign direct investments and net foreign institutional investments. However, they found that deficits in current account have negative effect on stock market index.

It is clearly seen that the empirical investigation shows that there are many macroeconomic variables contribute significantly to the development of the stock market in investigated countries. These variables including investment, banking sector development, and income are expected to have a positive effect on the stock market development. Moreover, according to the literature, remittances are expected to have a positive impact on market capitalisation ratio due to the fact that remittance flows are a source of private saving, and hence stimulating investing in the stock market. However, for the case of Jordan, a study (El-Nader \& Alraimony, 2013) found a negative relationship. Also the current study differ from El-Nader \& Alraimony, 2013 by employing a recent methodology, to capture both the long run and short run effects of the macroeconomic variables suggested by the literature on the financial development indicator.

\section{Data and Model Specification}

\subsection{Data}

The data series used in this paper obtained from annual reports of the central bank of Jordan and the major financial indicators published in the annual bulletins of the ASE, for the period 1978-2016 and it is expressed in million Jordanian dinars. Following the previous literature regarding the determinants of stock market development, a set of 
variables are included in this analysis to provide a comprehensive investigation of the Jordanian stock market development.

The stock market development's indicator used in this paper is in line with previous literature, where the work regarding stock market development and economic growth have employed number of indicators including the turnover index, which is calculated as the total stock value traded divided by the total market capitalisation (TO).

This indicator reflects the two main indicators of the stock market development. First, market capitalisation ratio, as defined in the ASE, represents the number of subscribed shares times the last closing prices of the company divided by GDP. This ratio measures the size of the stock market (La Porta et al. (1997), Levine and Zervos (1998), Li (2007)). Moreover, these studies find that the ratio of market capitalisation is strongly correlated with the development level in stock market in many economies.

The other indicator variable is measuring the stock market liquidity, where the increase in the liquidity in the stock market might lead to increase the amount traded and saving invested in the market and that will definitely affect stock market development. This variable is calculated by the total stock value traded divided by GDP.

The model used in our analysis look at the potential impact of macroeconomic variables on the stock market development indicator. We therefore include the total amount of workers' remittances as a share of GDP (REMY). In addition, three more explanatory variables are used in the estimated equation. The equation includes other macroeconomic variables that have been argued to have significant effects on stock market development. These variables include the level of income expressed by real GDP per capita (RGDPP), investment expressed by the gross fixed capital divided by GDP (IY), and a monetary variable expressed by the ratio of broad money (M2) to the GDP (M2Y).

The income level has been found to have a significant positive effect on stock market development as higher income will produce a higher propensity of consumers to invest in the stock market, and that will affect the market capitalisation positively. With respect to the investment level, the ratio of the gross fixed capital formation to GDP is widely used as a key determinant of the stock market in the literature and it is expected to have a positive effect on stock market, especially on the market capitalisation indicator. We also use a variable that reflects the size of overall banking sector through including M2Y in our analysis. This is used as a proxy of the financial depth and it is expected to have a significant positive impact on stock market variables (Levine and Zervos, 1998).

The series used are annual over the period 1978-2016. This is due to the data availability. Table 1 presents descriptive statistics of stock market development indicator and the explanatory variables.

Table 1. Descriptive statistics

\begin{tabular}{llllll}
\hline & TO & REMY & IY & M2Y & RGDPP \\
\hline Mean & 0.757 & 0.181 & 0.255 & 1.110 & 7.044 \\
\hline Standard Deviation & 0.134 & 0.038 & 0.063 & 0.159 & 0.132 \\
\hline Sample Variance & 0.018 & 0.001 & 0.004 & 0.025 & 0.018 \\
\hline Count & 39 & 39 & 39 & 39 & 39 \\
\hline
\end{tabular}

\subsection{Model Specification}

Following the literature on stock market development, a general model is considered to formulate empirically the determinant function of the stock market in Jordan, which could be expressed as:

$$
T O_{t}=f\left(R E M Y_{t}, M 2 Y_{t}, I Y_{t}, R G D P P_{t}\right)
$$

The model is estimated depending on an Autoregressive Distributed Lag (ARDL) approach by Pesaran and Shin (1998) and Pesaran et al. (2001), where this procedure allows us to apply the model regardless of the stationarity of the variables. The ARDL approach, also known as the ARDL bounds testing, has numerous advantages which make it preferable over other methods in estimating the long-run co-integration relationships. The main advantage is that the model is a single equation which is will be easy to interpret.

Following Pesaran and Shin (1998) and Pesaran et al. (2001), a general ARDL $(p, q)$ model can be presented as follows: 


$$
\begin{gathered}
y_{t}=\alpha_{0}+\alpha_{1} t+\sum_{i=1}^{p} \varphi_{i} y_{t-i}+\dot{\beta} x_{t}+\sum_{i=0}^{q-1} \hat{\beta}_{l}^{*} \Delta x_{t-i}+u_{t} \\
\Delta x_{t}=P_{1} \Delta x_{t-1}+P_{2} \Delta x_{t-2}+\cdots+P_{s} \Delta x_{t-s}+\varepsilon_{t}
\end{gathered}
$$

where $y_{t}$ represents the dependent variable, $x_{t}$ is a vector of explanatory variables and $u_{t}, \varepsilon_{t}$ are uncorrelated error terms with zero mean and constant variance. The model can be rewritten as:

$$
\varphi(L) y_{t}=\alpha_{0}+\alpha_{1} t+\sum_{i=0}^{k} \dot{\beta}_{l}(L) x_{t}+u_{t}
$$

Where $\varphi(L)=1-\varphi_{1} L-\varphi_{2} L^{2} \ldots-\varphi_{p} L^{p}, \dot{\beta}(L)=\beta_{0}-\beta_{1} L-\beta_{2} L^{2} \ldots-\beta_{q} L^{q}$, and $L$ is the lag operator. For simplicity define:

$$
\delta=\frac{\alpha_{1}}{1-\varphi} \text { and } \theta=\frac{\beta}{1-\varphi}
$$

Then $y_{t}$ can be expressed as:

$$
y_{t}=\mu+\delta t+\sum_{i=0}^{k} \dot{\theta}_{l}(L) x_{t}+v_{t}
$$

Where $\mu=\frac{\alpha_{0}}{1-\varphi}-\left(\frac{\varphi}{1-\varphi}\right) \delta$, and $v_{t}$ represents the error term.

The long-run co-integrating vector can be expressed as:

$$
y_{t}-\hat{\theta}_{0}-\hat{\theta}_{1} x_{1 t}-\hat{\theta}_{2} x_{2 t}-\cdots-\hat{\theta}_{k} x_{k t}=v_{t}
$$

Using the lag and first differences of $y$ and $x$, we obtain:

$$
\Delta y_{t}=\beta_{0}+\sum_{i=1}^{r} \beta_{i} y_{t-i}+\sum_{j=i}^{k} \sum_{i=1}^{r} \delta_{j i} x_{j, t-i}+\sum_{i=1}^{r} \pi_{i} \Delta y_{t-i}+\sum_{j=1}^{k} \sum_{i=1}^{r} \gamma_{j i} \Delta x_{j, t-i}+u_{t}
$$

Where $\beta_{0}$ is a deterministic variable, $j$ is the number of explanatory variables, $r$ is the number of lags selected based on the information criteria, and $u_{t}$ is a white noise disturbances. The implementation of this technique involves two stages. First one, test for the existence of co-integration relationship among $y_{t}$ and $x_{j t}$ variables by the bounds test, using F-test. The test null hypothesis that there is no co-integration relationship among the variables, and can be conducted as a joint significance test on lagged level variable's coefficients as follows:

$H_{0}: \beta_{\mathrm{i}}=\delta_{\mathrm{ji}}=0 \quad \forall i=1,2, \ldots r$ and $j=1,2, \ldots k$

The computed $F$ test gives two sets of critical values, bounds, one set based on the assumption that all variables in the ARDL model are $I(1)$, and the other set assumes that all variables are $I(0)$.If the calculated $\mathrm{F}$ is higher than the upper critical bound, then the null hypothesis is rejected, therefore a co-integration relationship between the variables exists. If the test statistic is below the lower critical bound, then the null hypothesis cannot be rejected. And if the calculated F-test is between the bounds, then the test cannot give a conclusive inference.

In the second stage, if the long-run relationship exists, then the long-run and short-run coefficients of the equation (8) can be estimated.

The investment function can be presented as follows:

$$
\Delta T O_{t}=\beta_{0}+\sum_{i=1}^{p} \beta_{i} T O_{t-i}+\sum_{i=0}^{p} \sum_{j=1}^{k} \gamma_{j i} \Delta D E P_{j, t-i}+\sum_{j=1}^{k} \delta_{j} D E P_{j, t-1}+\varepsilon_{t}
$$

Where $\Delta$ denotes the first difference, and $p=1,2$ is the number of lags determined by information criteria, and $k$ is the number of independent variables, and $D E P_{t}$ represented a vector of the explanatory variables. 


\section{Empirical Results}

\subsection{Unit root Tests}

To test the level of integration in the data, the presence of the unit root in each variable were tested. The Augmented Dickey-Fuller (ADF) and Phillips-Perron (PP) unit root tests applied to test the stationary hypothesis for each series. Table 2 summarizes unit root tests results.

Table 2. Unit root tests results

\begin{tabular}{llllll}
\hline & ADF & & PP & Summary \\
\cline { 2 - 5 } & Level & 1st Difference & Level & 1st Difference & \\
\hline $\boldsymbol{T O}$ & $-4.088^{* *}$ & & $-3.895^{*}$ & & $I(0)$ \\
\hline $\boldsymbol{R E M Y}$ & -2.704 & $-3.191 * *$ & -1.530 & $-4.974 *$ & $I(1)$ \\
\hline $\boldsymbol{I Y}$ & -1.668 & $-4.947 *$ & -1.869 & $-4.958^{*}$ & $I(1)$ \\
\hline $\boldsymbol{M} 2 \boldsymbol{Y}$ & -2.239 & $-3.171^{* *}$ & -2.237 & $-6.659 *$ & $I(1)$ \\
\hline $\boldsymbol{R} \boldsymbol{G D P P}$ & -1.876 & $-4.114 *$ & -1.904 & $-4.017 *$ & $I(1)$ \\
\hline
\end{tabular}

ADF, Augmented Dickey-Fuller; PP, Phillips-Perron; For critical values: 1\% -3.616, 5\% -2.941.

$*$ Significant at $1 \%$ and $* *$ significant at $5 \%$.

For the level variables, under ADF and PP the null hypothesis of a unit root cannot be rejected at the 5\% significance level, except for TO which can be rejected at level $1 \%$. However, the null that the first difference of the variables has unit root is rejected at the $5 \%$ and $1 \%$ level.

\subsection{Bounds Test}

In order to check the existence of a co-integration relationship among the variables, the bounds test, proposed by Pesaran et al. (2001), is implemented, which is based on testing the null hypothesis of no co-integration relationship among the variables. The test uses the F-statistic on equation (9):

$$
\Delta T O_{t}=\beta_{0}+\beta_{1} T O_{t-1}+\gamma_{1} \Delta M 2 Y_{t}+\delta_{1} R E M Y_{t-1}+\delta_{2} M 2 Y_{t-1}+\delta_{3} I Y_{t-1}+\delta_{4} R G D P P_{t-1}+\varepsilon_{t}
$$

Where the null and the alternative hypotheses are constructed as follows:

$$
H_{0}: \beta_{0}=\beta_{1}=\delta_{1}=\delta_{2}=\delta_{3}=\delta_{4}=0
$$

$H_{1}$ : At least one is not zero

Table 3. Bound test results

\begin{tabular}{llll}
\hline \multirow{2}{*}{ F statistic } & \multicolumn{2}{l}{ Critical values* } & \\
\cline { 2 - 4 } & Sig level & Lower bound & Upper bound \\
\hline $\mathbf{7 . 3 4 9}$ & $5 \%$ & 2.86 & 4.01 \\
\cline { 2 - 4 } & $10 \%$ & 2.45 & 3.52 \\
\hline
\end{tabular}

From Table 3, the calculated F-statistics (7.35) is exceeding the upper critical bound at the 5\% level of significance. Thus the null hypothesis of no co-integration can be rejected, so only one co-integration relationship exists in the model.

\subsection{Estimation Results}

The ARDL (1, 0, 1, 0,0) was selected based on the consideration of coefficient significant, goodness of fit, and model stability. Thus number of variables eliminated, such as inflation and interest rate, according to the significance level. Then the co-integrating form is (Prob. in brackets):

$$
\begin{gathered}
\Delta T O_{t}=-0.89 T O_{t-1}-0.47 \Delta R E M Y_{t}+0.29 \Delta M 2 Y_{t}+0.55 \Delta I Y_{t}+0.21 \Delta R G D P P_{t} \\
(0.000)
\end{gathered}
$$


The coefficient of $\mathrm{TO}_{t-1}$, that measures the speed of adjustment, appears to be negative and less than 1 in magnitude, about -89 percent, and statistically significant at $1 \%$ level. Thus, it seems that the model fast to be adjusted, about a year and two months.

The long-run relationship can be estimated as (Prob. in brackets):

$$
\begin{gathered}
T O_{t}=-1.651-0.523 R E M Y_{t}+0.611 M 2 Y_{t}+0.617 I Y_{t}+0.239 R G D P P_{t} \\
(0.000)(0.016)
\end{gathered}
$$

The above estimation represents the long-run relationship between stock market development indicator and its determinants. The stock market turn-over indicator depends positively on financial depth indicator, investment, and real GDP per capita, and negatively on the remittances as most of Jordanian workers' remittances is used for consumption purposes rather than investment in the stock market (El-Nader \& Alraimony, 2013). All signs and coefficients magnitude seem to be consistent with the economic theory.

\begin{tabular}{|c|c|}
\hline & Dependent variable: $T O$ \\
\hline \multirow[t]{2}{*}{$T O_{t-1}$} & 0.107 \\
\hline & $(0.389)$ \\
\hline \multirow[t]{2}{*}{$R E M Y_{t}$} & -0.467 \\
\hline & $(0.024)$ \\
\hline \multirow[t]{2}{*}{$M 2 Y_{t}$} & 0.291 \\
\hline & $(0.029)$ \\
\hline \multirow[t]{2}{*}{$M 2 Y_{t-1}$} & 0.255 \\
\hline & $(0.066)$ \\
\hline \multirow[t]{2}{*}{$I Y_{t}$} & 0.551 \\
\hline & $(0.000)$ \\
\hline \multirow[t]{2}{*}{$R_{G D P P_{t}}$} & 0.213 \\
\hline & $(0.001)$ \\
\hline \multirow[t]{2}{*}{ Constant } & -1.474 \\
\hline & $(0.002)$ \\
\hline $\mathbf{R}^{2}$ & 0.882 \\
\hline$\overline{\boldsymbol{R}}^{2}$ & 0.858 \\
\hline $\mathbf{S E}$ & 0.038 \\
\hline F-statistic & 37.195 \\
\hline $\operatorname{Prob}($ F-statistic) & 0.000 \\
\hline
\end{tabular}

Table 4. ARDL(1,0,1,0,0) estimation results of TO equation

Table 4 represents the results of the ARDL estimation of the short run for the suggested model. The banking development (and its lag), investment and real income have a positive effect on stock market development.

A more remittances received, negatively affect the stock market development, about 47 percent. In other words, any 1 percent increase in the remittances-to-GDP ratio, decreases the stock market development by about 47 percent. This result is different from the finding in the previous empirical literature (Billmeierand Massa, 2009; Raza et al. 2015). The reason due to that remittances received in Jordan is intended for investment in the real estate sector rather in the financial market.

The goodness of fit of the model is relatively high, and the overall model is significant. The regression specifications fit well and pass all diagnostic tests against serial correlation, non-normal residual, heterosedasticity, and incorrect functional form. Table 5 reports the diagnostic tests. 
Table 5. Diagnostic tests

\begin{tabular}{ll}
\hline LM test & $\mathrm{F}(1,29)=0.838[0.367]$ \\
\hline Normality test & $\chi^{2}(2)=1.722[0.426]$ \\
\hline Heteroskedasticity Test & $\mathrm{F}(6,30)=0.527[0.783]$ \\
\hline RESET test & $\mathrm{F}(1,29)=0.162[0.690]$ \\
\hline
\end{tabular}

\section{Conclusion and Policy Implications}

In this paper, we examined the long-run relationships and the short-run dynamics among an indicator of stock market development and macroeconomic variables using annual data for Jordan covering the period 1978-2016. The analysis used is based on cointegration tests, employing the ARDL bounds testing procedure.

The empirical results are mixed. The bounds test procedure finds cointegration evidence between financial development indicator and macroeconomic variables. The reported results show significant short-run effects of macroeconomic variables including investment, income, banking sector development, and remittances on stock market development indicator. The model goes to equilibrium in one year and two months. In the long run, all variables are significant and positively impact the stock market development, except remittances.

Findings may generally explain the highly use of remittances in consumption and construction activities in Jordan. There is a significant negative impact of remittance flows on stock market development confirms this fact. However, other variables have the expected impact on the development of stock market. Therefore, policymakers should take this fact in consideration when a monetary policy taken, or encouraging investment policies structured.

\section{References}

Aggarwal, R., \& Peria, M. S. M. (2006). Do workers' remittances promote financial development? Vol. 3957. World Bank Publications. https://doi.org/10.1596/1813-9450-3957

Billmeier, A., \& Massa, I. (2009). What drives stock market development in emerging markets-institutions, remittances, or natural resources?. Emerging Markets Review, 10(1), 23-35. https://doi.org/10.1016/j.ememar.2008.10.005

El-Nader, H. M., \& Alraimony, A. D. (2013). The macroeconomic determinants of stock market development in Jordan. International Journal of Economics and Finance, 5(6), 91. https://doi.org/10.5539/ijef.v5n6p91

Garcia, V. F., \& Liu, L. (1999). Macroeconomic Determinants of Stock Market Development. Journal of Applied Economics, 2(1).

Giuliano, P., \& Ruiz-Arranz, M. (2005). Remittances, financial development, and growth. Working Paper 05/234. International Monetary Fund.

Ho, S. Y. (2017). The Macroeconomic Drivers of Stock Market Development: Evidence from Hong Kong.

Ho, S. Y., \& Njindan Iyke, B. (2017). Determinants of stock market development: a review of the literature. Studies in Economics and Finance, 34(1), 143-164. https://doi.org/10.1108/SEF-05-2016-0111

Ho, S. Y., \& Odhiambo, N. M. (2018). Analysing the Macroeconomic Drivers of Stock Market Development in the Philippines. Cogent Economics \& Finance. https://doi.org/10.1080/23322039.2018.1451265

Kemboi, J. K., \& Tarus, D. K. (2013). Macroeconomic determinants of stock market development in emerging markets: Evidence from Kenya. Review of Quantitative Finance and Accounting, 4(9), 84-95.

Kumar, G. \& Batra, S. (2017). Stock Market Index and Macro Economic Variables in India: An Empirical Relationship. Asian Journal of Research in Banking and Finance, 7(2), 45-60. https://doi.org/10.5958/2249-7323.2017.00007.4

La Porta, R., Lopez-de-Silanes, F., Shleifer, A., \& Vishny, R. W. (1997). Legal determinants of external finance. Journal of Finance, 1131-1150. https://doi.org/10.1111/j.1540-6261.1997.tb02727.x

Levine, R., \& Zervos, S. (1996). Stock market development and long-run growth. The World Bank Economic Review, 10(2), 323-339. https://doi.org/10.1093/wber/10.2.323

Levine, R., \& Zervos, S. (1998). Stock markets, banks, and economic growth. American Economic Review, 537-558. 
Li, T. M. (2007). The will to improve: Governmentality, development, and the practice of politics. Duke University Press. https://doi.org/10.1215/9780822389781

Matadeen, S. J. (2017). The Macroeconomic Determinants of Stock Market Development from an African Perspective. Theoretical Economics Letters, 7(07), 1950-1964. https://doi.org/10.4236/tel.2017.77132

Mundaca, G. (2005). Can remittances enhance economic growth? The role of financial markets development. Unpublished, Department of Economics, University of Oslo, Oslo, Norway.

Pesaran, M. H., \& Shin, Y. (1998). An autoregressive distributed-lag modelling approach to cointegration analysis. Econometric Society Monographs, 31, 371-413. https://doi.org/10.1017/CCOL0521633230.011

Pesaran, M. H., Shin, Y., \& Smith, R. J. (2001). Bounds testing approaches to the analysis of level relationships. Journal of applied econometrics, 16(3), 289-326. https://doi.org/10.1002/jae.616

Prakash, N. (2009). The development impact of workers' remittances in Fiji'. Unpublished Masters Thesis, Massey University, Palmerston North New Zealand.

Raza, S. A., Jawaid, S. T., Afshan, S., \& Karim, M. Z. A. (2015). Is stock market sensitive to foreign capital inflows and economic growth? Evidence from Pakistan. Journal of Chinese Economic and Foreign Trade Studies, 8(3), 142-164. https://doi.org/10.1108/JCEFTS-03-2015-0012

Sukruoglu, D., \& Nalin, H. T. (2014). The macroeconomic determinants of stock market development in selected European countries: Dynamic panel data analysis. International Journal of Economics and Finance, 6(3), 64. https://doi.org/10.5539/ijef.v6n3p64 